\title{
Developing Web-Based Lessons to Improve Khon Kaen University Graduate Students' Reading Skills
}

\author{
Theptewan Duangdee*, Poranee Deerajviset \\ Department of English Language, Faculty of Humanities and Social Sciences, Khon Kaen University, \\ Khon Kaen, Thailand. \\ * Corresponding author. Tel.: +669 09700213; email: theptewan.d@gmail.com \\ Manuscript submitted May 1, 2017; accepted July 11, 2017. \\ doi: 10.17706/ijeeee.2018.8.1.44-50
}

\begin{abstract}
The aims of this study were to examine Khon Kaen University graduate students' reading skills after learning via web-based lessons and to investigate the attitudes of Khon Kaen University graduate students toward learning via web-based lessons to improve their reading skills. The participants were 63 graduate students who enrolled in Reading in English for Graduate Students course in the first semester of academic year 2016. The instruments used in this study were 1) the pretest and the posttest, 2) web-based lessons, 3) the questionnaire, and 4) the interview. The research findings revealed that the mean score of the posttest was significantly higher than the pretest which means that students' reading skills were significantly increased at 0.05 level after learning via web-based lessons ( $t$-Test $=10.417)$. Moreover, the average mean scores of web-based exercises were considered as high level $(\mathrm{M}=74.68$, S.D. $=8.56)$. According to the analysis from the questionnaire, the results showed that students' attitudes toward learning via web-based lessons were at a high level $(M=4.03$, S.D. $=0.71)$. From the interview, students stated that web-based lessons are effective tools to learn and they found that it is fun to learn via web-based lessons. Students also suggested that web-based lessons should be integrated with other English skills.
\end{abstract}

Key words: Graduate students, moodle, reading skills, web-based lessons.

\section{Introduction}

Thai graduate students are necessary to spend their extreme effort to read English texts in order to gain a deep understanding of research articles and academic texts in order to gain an idea and relevant information [1]. However, most of Thai graduate students are not well-proficient in English reading [1]. Moreover, graduate students who are considered as adult learners who do not learn English language as easy as youngsters or children" because their time-consuming to understand something, less reading comprehension abilities, and age implies less memory. [2]. Besides, due to their multiple responsibilities such as their full-time jobs, adult learners do not ultimately expose to learn since they may attend the class with low energy [3].Therefore, it is necessary to assist graduate students with appropriate learning approach to improve their reading skills.

Web-based instruction is one learning approach to promote autonomous learning [4]. Moreover, web-based instruction is considered as an appropriate learning tool to assist adult learners to learn because adult learners seemed to be more self-contained than young learners [3]. For the software, Modular Object-Oriented Dynamic Learning Environment (Moodle) is a very useful and it is suggested for all teachers [5], [6]. 
Research studies using web-based instruction to teach reading skills, especially in graduate level, has been found less [7]. Therefore, this study employed web-based lessons to develop Thai graduate students as previous studies showed that web-based instruction is very helpful to assist students' reading skills [7][12]. This study aims to develop web-based lessons in order to improve Khon Kaen University Graduate students based on these following research questions: (1) To what extent can web-based lessons improve Khon Kaen University graduate students' reading skills?, and (2) What are Khon Kaen University graduate students' attitudes toward learning via web-based lessons to improve their reading skills?

\section{Literature Review}

\subsection{Reading Strategies}

Considering the role of reading strategies, the terms "skill" and "strategy" are used interchangeably. However, there are some different meanings between them. McDonought [13] distinguished strategy as conscious action which students reach their desired goal, and skill is a strategy that becomes automatic. Anderson [14] focused on students as consciously learn and practice specific reading strategies. The strategies will move from conscious to unconscious which is similar to moving from strategies to skills.

Reading strategies are very useful to readers to comprehend the text when they are struggling with difficulties. In Thai EFL context, readers are not able to solve the problems when they are struggling in reading difficult texts [15]. Reading strategies can be one of the techniques to develop students' reading ability. Even though reading strategies are identified and classified into different ways, this study focuses only on the reading strategies including guessing meaning from context, scanning, making inferences, identifying the topic and main idea, identifying the pattern, and skimming which proposed by [16]-[18]. These reading strategies are necessary for Khon Kaen University graduate students in order to read English academic texts because most of researcher (e.g., [19], [20]) stated that these reading strategies are considered as necessary reading strategies for academic reading.

\subsection{Web-Based Instruction}

Web-based instruction is considered as popular and efficient in EFL learning [19]. Web-based instruction also promotes students to become autonomous learners [21]. Moreover, learning via web-based instruction constructs the constructivism theory which focuses on the student's ability to create an understanding by themselves and a new knowledge by using their prior knowledge and experience. The role of teachers is a facilitator. Joshi [22] claimed that web-based instruction will not substitute teachers, but it can supplement teachers and help students to practice languages. In addition, Schunk [23] also claimed that online learning environment also motivates students to have a self-regulation which focuses on students' ability to plan, monitor, and direct their own learning. Self-regulation is a mental process which is based on constructivism theory. In addition, web-based instruction influences students to learn and produce the valuable and creative learning.

In developing and designing web-based lessons, it is essential to be aware of components of web-based instruction. Components of web-based instruction are clustered into content development including instructional design, multimedia component, internet tools, computer and storage device, connections and service providers, severs, and browsers [24]-[25]. Moreover, in web-based learning environment, students can interact with others by the interactive components which include browsers, servers, and instructional design. Besides, browsers, authoring programs, and web-based conferencing are multimedia which can be designed to address all students' learning styles by incorporating a variety of multimedia elements such as texts, graphics, audio, and video, animation. Moreover, web-based instruction can be remarkably convenient for students, instructors, and institutions [24]. Students can register, do coursework, conduct research, and 
communicate with the instructor via the internet without having to physically travel. Finally, web-based instruction facilitates online evaluation by form, e-mail, and database [24]. Online evaluation includes both assessment of students and evaluation of the instructor. Individual testing, participation in group discussions, questions, and portfolio development can be incorporated into a web-based instruction.

The software used in this study is Moodle which Teachers can easily construct the web-based course in terms of online discussion, surveys and quizzes, sharing and uploading materials, reviewing assignments, and recording grades. Moreover, Sarica and Cavus [12] stated that students can be a part of group by communicating with others in order to motivate them to gain an effective learning. In conclusion, Moodle is very beneficial to assist graduate students in language learning especially in reading skills.

\section{Methodology}

\subsection{Participants}

The participants in this study were sixty-three graduate students who enrolled in Reading in English for Graduate Students, the first semester of academic year 2016, Khon Kaen University. The participants were selected by purposive sampling which is "the judgment of the researcher as to who can provide the best information to achieve the objectives of the study" ([26], p. 179).

\subsection{Research Design}

This study was conducted by one group pretest-posttest design which uses the same group for both measurements ...and can be used when an intervention (treatment) affects a specific target group" [27]. Participants had to take pretests before the treatment was intervened or learning through web-based lessons. Then, the posttest was conducted to measure of participants' achievement after learning via web-based lessons.

\subsection{Research Instruments}

In this study, the research instruments include (1) the pretest and the posttest, (2) web-based lessons, (3) the questionnaire, and (4) the interview.

For the pretest and the posttest, the test was created based on Cambridge English: Advanced test which is equal to Common European Framework Reference at $\mathrm{C} 1$ level, which is the requirement for graduate students in the hope that students will become proficient readers [28]. The test encompasses six reading strategies: (1) guessing meaning from context, (2) scanning, (3) making inferences, (4) identifying the topic and main idea, (5) identifying the pattern (6), and skimming, which are considered as necessary strategies for graduate students (e.g . [14], [19], [20]). After conducting the pretest and the posttest, the tests were checked and approved by the experts. The Item-Objective Congruence Index (IOC) form was provided to the experts to check the appropriateness of the question items of the pretest and posttest taken to try out with three non-participants of the study. In this study, the IOC [29] was to ensure the validity in terms of the content between the questions and the objectives of the study. In addition, in order to ensure the reliability coefficient of the pretest and the posttest, Kuder-Richardson (KR-20) formula was used in the study. The results of KR-20 were 0.79 for the pretest and 0.75 for the posttest.

For the web-based lessons, the design of web-based lessons is based on Khon Kaen University (KKU) Moodle which is the host page for web-based lessons. The content of each web-based lesson was created based on Cambridge English: Advanced (CAE) comparing to CEFR as C1 level [30]. CAE also provides the handbook for teachers and teaching resources (e.g., lesson plans) in order to create the lessons. The teachers were guided to teach students how to use reading strategies effectively. In this study, web-based lessons consisted of seven main sections: 1) introduction, 2) objectives, 3) instructions, 4) web-based reading strategy lessons, 5) web-based reading exercises 6) grammar help, 7) online dictionaries, and 8) 
glossary. First, students are required to log in to KKU Moodle to see the introduction, objectives, and instructions of the course. Then, students spent time in the reading strategy lessons. Meanwhile, students are able to click a link on "Grammar help", "Online Dictionaries", and "Glossary" while learning. After that, six exercises provided to the students. The exercises were divided into three parts. Students were asked to complete each part of exercises respectively. Each exercise contained twenty items in each part. True-false exercises provided in part 1, multiple choices in part 2, and drag \& drop in part 3 respectively.

For the questionnaire, the participants were required to respond to 20 statements according to the 1-5 Likert scale by scoring the level of attitudes [31]. In addition, the last part of questionnaire included an open-ended question to encourage suggestions. The objective of the questionnaire is to investigate the attitudes of participants towards learning via web-based lessons in order to develop their reading skills.

For the interview, researcher conducted semi-structured interview which has a list of questions about the use of web-based lessons. Students had to answer the following questions: (1) How do web-based lessons support you in improving reading skills? (2) What are the problems you found in learning via web-based lessons? How do you overcome the problems? (3) What is/are your suggestion(s) after you learned via web-based lessons?

\subsection{Data Collection}

The procedure of data collection was segmented into ten weeks. For the first week, the students were provided with the orientation part. The students were introduced to the objectives of the study and the instructions. Next, participants were asked to preview the use of computer such as how to log in, put passwords, and start learning web-based lessons in each lesson. They also had to check for the computers' readiness. For week 2 , the pretest was provided. Then, students were guided to basically study lesson 1 : guessing meaning from context in week 3. After that, from week 4-8, they had to take reading strategy lessons and do web-based exercises in each week including scanning, making inferences, identifying the topic and main idea, identifying the pattern, and skimming respectively. For week 9, the students were required to take the posttest. Finally, for week 10, the questionnaire was distributed and the interview was conducted.

\subsection{Data Analysis}

The data were analyzed according to each research instrument. For the pretest and the posttest, the data were analyzed by the t-test which "compares the means of two groups, and it also helps determine how confident the researcher can be that the differences found between two groups", ([31], p. 231) by using SPSS program. Moreover, the SPSS program was also used to analyze the data gained from the questionnaire to investigate student's attitudes toward using web-based lessons, which calculates the mean (M) and the standard deviation (S.D.). Lastly, from the interview, the data were descriptively analyzed by the verbal answer gained from the participants in content analysis which views data as representations not of physical events, but of texts, images and expressions that are created to be seen, read, and interpreted [32]

\section{Findings and Discussion}

In the pretest and the posttest, table 1 provides the overall results which were reported statistically by using SPSS to find out the p-value (t-test) by comparing the mean scores between the pretest and the posttest.

As we can observe from the table 1, participants showed better performance at the posttest than the pretest, which has significant differences at 0.05 levels in the subjects' performance in reading skills after learning via web-based lessons. The result indicated that web-based lessons are the effective tool to improve students' reading skills. 
In web-based exercises, average of all participants' mean scores was 74.68 out of 100 . For the web-based exercises, lesson 1 guessing meaning from context part 1 (true-false) got the highest scores (81.51) because the first lesson interests students to do their best [33]. However, lesson 6 skimming part 3 (drag \& drop) got the lowest score (44.13). It was the last lesson and student may lack of motivation to learn and tended to pay less attention on the lesson [34].

Table 1. The Comparison between the Mean Scores of the Pretest and the Posttest

\begin{tabular}{cccccc}
\hline \hline Tests & Students & $\begin{array}{c}\text { Mean scores } \\
(\mathbf{M})\end{array}$ & S.D. & t-Test & p-value \\
\hline Pretest & 63 & 23.48 & 8.99 & \multirow{2}{*}{10.417} & $* * 0.000$ \\
\hline Posttest & 63 & 35.06 & 8.87 & & \\
\hline \hline $\mathbf{p}<\mathbf{0 . 0 5}$ & & & &
\end{tabular}

In the questionnaire, students had overall highly-perceived attitudes toward learning via web-based lessons ( $M=4.03$, S.D. = 0.71). For an open-ended question part, students gave comments that web-based lessons were anywhere and anytime learning. They also commented that it was fun and interesting to learn. However, the participants claimed some problems in learning via web-based lessons such as low-speed internet connection, short time given, and the instability Moodle of system.

In the interview, student reported about how web-based lessons support them in apply reading strategies effectively when reading to their related-field text. Moreover, they reported about the problems while learning via web-based lessons. The causes of the problem are low-speed internet connection, the instability of Moodle server, and some students' own problems such as their eyes sight. They also suggested that web-based lessons should provide more outside resources about reading strategies. In addition, listening and speaking should be integrated in the web-based lessons.

To answer question No. 1, it can be seen that students have a good understanding of web-based lessons; as a result, they could do web-based exercises effectively. Most of students had an improvement of using reading strategies, and they became more skilled readers. They also claimed that web-based lessons can facilitate students 'reading comprehension ability and strategy use, and they can apply the reading strategies explicitly during the course. The results were consistent to the past studies ([7]-[10])

To answer question No. 2, regarding student's attitudes gained from the questionnaire and the interview, the overall findings revealed that most students had high positive attitudes towards learning via web-based lessons as the beneficial and motivating tools for learning. Students also saw web-based lessons as a useful tool for learning, an anywhere anytime learning tool, and an interesting and motivated learning tool. However, a few students reported that the problems while learning via web-based lessons were low-speed internet connection, instability of the Moodle system, and short-time given. The findings were congruent to [11] and [12].

\section{Conclusion}

In conclusion, web-based lessons are considered as an effective and useful tool for improving Khon Kaen University graduate students' reading skills. Moreover, most of students gained positive attitudes toward learning via web-based lessons. According to the results, the students would become proficient readers if they practice learning via web-based lessons a lot. On the other hand, the recommendations from this study are that (1) the study should provide more reading strategies which are necessary for academic reading, (2) the study should provide 3D animation, and (3) the study should provide delayed posttest in order to test students' retention after learning via web-based lessons. The recommendations would provide insight to develop research in the field of web-based instruction in language teaching and learning in the future. 


\section{References}

[1] Pimsarn, P. (2009). A comparative study of reading strategies instruction on graduate students' reading comprehension. Language Institute Journal, 4, 61-75.

[2] Flórez, E. G., Pineda, J. D., \& García, N. M. (2012). EFL students' perceptions about a web-based English reading comprehension course. PROFILE, 14(2), 113-229.

[3] Cozma, M. (2015). The challenge of teaching English to adult learners in today's world. Procedia Social and Behavioral Sciences, 197, 1209-1214.

[4] Wang, J. (2010). How to develop college students' autonomous English learning skills take reading course in joint-program in HCFT as an example. English Language Teaching, 3(3), 221-228.

[5] Martinez, M., \& Jagannathan, S. (2008). Moodle: A low-cost solution for successful e-learning. Learning Solutions, 1-8.

[6] Meurant, R. (2010). How computer-based internet-hosted learning management systems such as Moodle can help develop L2 digital literacy. International Journal of Multimedia and Ubiquitous Engineering, 5(2), 19-26.

[7] Dehghanpour, E., \& Hashemian, M., (2015). Efficiency of using web-based approach to teach reading strategies to Iranian EFL learners. English Language Teaching, 8(10), 30-41.

[8] Arismendi, G. F. A., Colorado, L. D., \& Grajales, M. L. F. (2011). Reading comprehension in face-to-face and web-based modalities: Graduate students' use of reading and language learning strategies in EFL. Colombian Applied Linguistics Journal, 13(2), 11-28.

[9] Hsieh, P. C., \& Ji, C. H. (2013). The Effects of Computer-Mediated Communication by a Course Management System (MOODLE) on English Reading Achievement and Perceptions. Paris: Atlantis Press.

[10] Kongphet, N. (2014). Integration of blended e-learning to teach reading strategies to EFL students: A case study of undergraduate students at Ubon Ratchathani Rajabhat University, Thailand. International Journal of Information Technology and Computer Science (IJIECS), 15(2), 34-39.

[11] Osorno, J., \& Lopera, S. (2012). Interaction in an EFL reading comprehension distance web-based Course. Íkala, revista de lenguaje y cultura, 17(1), 45-59.

[12] Sarica, G., \& Cavus, N. (2009). New trends in 21st century English learning. Procedia Social and Behavioral Sciences, 1, 439-445.

[13] McDonough, S. G. (1995). Strategy and Skill in Learning a Foreign Language. New York: Edward Arnold.

[14] Anderson, N. J. (2003). Practical English Language Teaching, 67-86. New York, NY: McGraw-Hill, Inc.

[15] Chawwang, N. (2008). An Investigation of English Reading Problems of Thai 12th-Grade Students in Nakhonratchasima Education Regions 1,2,3 and 7. Published master's thesis, Srinakarinwirot University, Thailand.

[16] Anderson, N. J. (1999). Exploring Second Language Reading: Issues and Strategies. Boston: Heinle \& Heinle.

[17] Brown, H. D. (2001). Teaching by Principle: An Interactive Approach to Language Pedagogy. White Plains, NY: Longman.

[18] Mokhtari, K., \& Reichard, C. (2002). Assessing students' metacognitive awareness of reading strategies inventory. Journal of Educational Psychology, 94(2), 249-259.

[19] Grabe, W. (2009). Reading in Second Language: Moving from Theory to Practice. New York, NY: Cambridge University Press.

[20] Floris, F. D., \& Divina M. (2009). A study on the reading skills of EFL university students. TEFLIN Journal, 20(1), 37-47.

[21] Kun, L. (2011). Web-based vocabulary learning in intensive reading. US-China Foreign Language, 9(8), 524-529. 
[22] Joshi, C. (2010). A paradigmatic shift of traditional language learning to computer-assisted language learning (CALL). International Research Journal, 1(5), 73-76.

[23] Schunk, H. D. (2009). Learning Theories: An Educational Perspective (5th edition). The United States of America: Pearson Prentice.

[24] Khan, B. H. (1998). Web-Based Instruction (WBI): An Introduction, Educational Media International. Englewood Cliffs, NJ. Educational Technology Publications.

[25] Nam, C. S., \& Smith-Jackson, T. L. (2006). Web-based learning environment: A theory-based design process for development and evaluation. Journal of Information Technology Education, 6, 23-46.

[26] Kumar, R. (2005). Research Methodology: A Step-by-Step Guide for Beginners (2nd edition). London: SAGE.

[27] Hernández, O. (2000). Environmental Education \& Communication for a Sustainable World: Handbook for International Practitioners (pp. 61-65). Washington, The United States: Academy for Educational Development.

[28] Cambridge English Language Assessment. (2016). Exam for higher education: A guide to setting your admission requirements. Cambridge University Press.

[29] Worakham, P. (2011). Educational Research [in Thai]. Mahasarakham, Thailand: Takkasila Publishing.

[30] Cambridge English Language Assessment. (2015). Cambridge English: Advance: A handbook for teachers. Cambridge University Press.

[31] Seliger, W. H., \& Shohamy, E. (1995). Second Language Research Methods. Oxford Oxford University Press.

[32] Krippendorff, K. (2004). Content Analysis: An Introduction to Its Methodology (2 ${ }^{\text {nd }}$ edition). California, The United stated: SAGE.

[33] Xiao, F. (2013). Motivational strategies in teaching English as a foreign language-applying motivational plan in TEFL. International Journal of Humanities and Social Science. 3(18), 257-262.

[34] Dişlen, D., (2013). The reasons of lack of motivational from the students' and teacher's voices. The Journal of Academic Social Science, 1(1), 35-45.

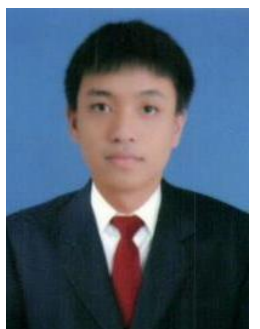

Theptewan Duangdee is studying a master degree of arts in English at the Faculty of Humanities and Social Sciences, Khon Kaen University, Thailand. He has got a bachelor degree of education in learning management in the field of English education (first class honors) at the Faculty of Education and Development Sciences, Kasetsart University, Kamphangsaen Campus. He currently works as a secondary English teacher. His research interests include technology-enhanced language learning, e-learning, web-based learning, second language acquisition, and learning management.

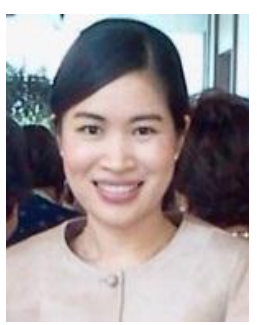

Poranee Deerajviset is currently an assistant professor at the Department of English Language, Faculty of Humanities and Social Sciences, Khon Kaen University, Thailand. She graduated with a bachelor of arts in English (First class honors) from Khon Kaen University. She received her master's degree in education from the University of Cambridge, UK and her $\mathrm{PhD}$ in education from the University of Sydney, Australia. Her research interests include second language writing and technology in language teaching and learning. 